\title{
A KÁVÉFOGYASZTÁSI SZOKÁSOK VIZSGÁLATA
}<smiles>CNC</smiles>

INVESTIGATING THE COFFEE CONSUMPTION HABITS \\ Debreceni Egyetem, Gazdaságtudományi Kar, Gazdálkodástudományi Intézet \\ (University of Debrecen, Faculty of Economics and Business, Institute of Applied Economics Sciences) \\ H-4032 Debrecen, Böszörményi út 138. \\ E-mail: olahbettina99@gmail.com
}

\begin{abstract}
si
Coffee consumption is a widespread activity nowadays all around the world. It is a very popular beverage, with many variants as are known. Caffeine can cause many effects in our bodies. These include health benefits and adverse effects. According to 2018 data, the annual per capita coffee consumption in Hungary was 3.1 kilograms, making it the 24th largest coffee consumption country in the world. The aim of the research was to reveal the coffee consumption habits at the domestic level, based on the results of a questionnaire survey based on secondary data collection. In our research, we have also placed great emphasis on examining the beneficial and harmful health effects of coffee consumption. Our further goal is to explore whether domestic consumers are aware of the health effects of coffee consumption. Our hypothesis, defined in connection with our research, was, "Those people who frequently consume coffee are unaware of the health effects of coffee". As a first step in our research we made a secondary data collection and our second step was the primary data collection. The basis of our primary research was the questionnaire we prepared, which was shared online. The size of the examined sample is 1664 people. The sample population does not statistically represent the population of Hungary, therefore we do not consider the survey to be representative, the results are only exploratory. Based on our research, we found out that although most of the people who consume coffee often are aware of the beneficial and harmful health effects of coffee, this is mainly true for women, but less so for men. Men are more likely to know only the harmful effects. Our results have shown that those who are aware of all the health-affecting properties of coffee are not more conscious of the amount of coffee consumed than those who are unaware of only the good, bad, or both of the properties.
\end{abstract}

KuLCSSZAVAK: egészségtudatos táplálkozás, fogyasztói szokások, kávéfogyasztás

JEL-KóDOK (JEL CODES): A13, P56

DOI: https://doi.org/10.20494/TM/8/1/5
KEYWORDS: healthy diet, consumer habits, coffee consumption 


\section{BEVEZETÉS - INTRODUCTION}

A kávéról elmondható, hogy a víz után, a világ második leginkább fogyasztott itala (CHRYSANT, 2017). Kijelenthető, hogy a világ minden pontján jól ismerik, azonban annak különböző változatait fogyasztják. A kávé őshazája Etiópia, de ma már közel 80 ország termeli a világon, a kávéövön belül, azaz a Ráktérítőtől egészen a Baktérítőig terjedő sávban. Az említett 80 ország közül körülbelül 50 ország exportra is termel kávét. A Földön 9,6 millió hektáron mintegy 8,3 millió tonna mennyiségü kávét termesztenek, hektáronként átlagosan o,86 tonnát. A legnagyobb termesztő Brazília, mivel a megtermelt összmennyiség mintegy 40\%-át adja (BENMETAN, 2018).

Világviszonylatban elmondható, hogy a kávéfogyasztás mértéke folyamatosan növekvő tendenciát mutat. Mindemellett a hazai fogyasztás mennyisége is évről évre magasabb. Kávéfogyasztás tekintetében Magyarország meglepő helyen szerepel a sorrendben. 2018as adatok alapján, a világ összes országának egy főre vonatkozó kávéfogyasztási szokásait tekintve, hazánk a 24. helyet foglalja el. Ez számszerüsítve, évente 3,1 kg kávé elfogyasztását jelenti, fejenként. A világranglistán, az első helyen Finnország áll, 9,6 kg/fővel, ezt követi Norvégia 7,2 kg/fővel, majd Hollandia 6,7 kg kávé fejenkénti fogyasztással (STATISTA, 2020).

A kávézásnak számos élettani hatása ismert. Ezek között az egészségre kedvező és kedvezőtlen hatásokat is tartunk számon. A kávécserjéket serkentő hatásuk miatt már az ókorban ismerték. Számos törzs vadászat és háború előtt, nyersen fogyasztotta a vörös színü kávébabokat. Az egyik legelterjedtebb monda főszereplőjének Khaldi tekinthető, aki a XV. században élt és pásztorként tevékenykedett, amely során megfigyelte a növény termésének az emberi szervezetre vonatkozó serkentő hatását. Megfigyelt tapasztalatait továbbadta a közeli kolostor szerzetesei számára, akik a magvakból főzetet készítve sötét színű italt állítottak elő. A későbbi időkben ez az ital szertartásaikon is szerepet játszott, hiszen gyakran előszeretettel fogyasztották azt (CROZIER et al., 2012).

Az egyik legkorábbi feljegyzés, a kávé egészségügyi hatásairól és magáról a kávéról, mint italról, egy augsburgi orvos, Leonhard Rauwolf nevéhez füződik, aki 1582-ben az akkor megjelent útleírásában tett róla említést: „Fekete, mint a tinta, de jót tesz a gyomornak.” Majd később egy páduai tanár, Prosper Alpino magáról a növényről készített leírást 1592-ben „Arbor bon cum fructu suo buna" néven egy egyiptomi növényfajokat ismertető, latin nyelvű múvében (RÁCZ, 2010). Hazánkban a XVII. században nem volt jellemző a kávéfogyasztás, az embereket nem érdekelte, hidegen hagyta és csak egy úri hóbortnak tartották. Egy időben azonban orvosságként is alkalmazták, mint enyhe fájdalomcsillapító vagy gyomor- és emésztési panaszok, ritkább esetekben pedig fulladás és másnaposság enyhítésére (RÁCZ, 2010).

A magvakból készült kivonatot gyakran alkalmazzák a likőriparban kávélikőrök ízesítésére, valamint élelmiszeripari termékek ízanyagaként is rendszerességgel használják. Mindezek mellett megemlítendő még az édességipar és a cukrászdák kávéfelhasználása is, mind lefözve, mind egész szemenként vagy szén formájában hasznosítva. (KHARE, 2007).

$\mathrm{Az}$ 1. táblázatban az egyes élelmiszerek koffeintartalma látható, milligramm/menynyiség értékben. Jól látható, hogy a hosszú-, a presszó- és a dupla kávé igen magas koffeintartalommal rendelkeznek. Megemlítendő még az energiaital, mely serkentő hatása felér nagyjából egy presszó kávé erejével (50-90 $\mathrm{mg} / 2$ dl). Mindazonáltal az instant kávé, a fekete- és a zöld tea koffeinszintje nagyjából egy skálán mozog. Egy pohár kóla 20-35 mg/2 dl koffeint tartalmaz. A csokoládét tekintve $3 \mathrm{dkg}$ nagyjából 10-30 mg koffeint tartalmaz, míg egy pohár kakaó 10-20 mg/2dl értékkel rendelkezik. Sokak számára meglepő az utolsó, a koffeinmentes kávé adata, hiszen bár nevében ott van a mentes szó, teljes mértékben nem tudják a koffeintől mentesíteni, így számolni kell vele, hogy ebben is nagyjából 3-4 mg/ 2 dl koffein található meg (MELION és TÚRY, 1992). 
Egyes élelmiszerek koffeintartalma (Caffeine Content of Certain Foods)

\begin{tabular}{lc}
\hline \multicolumn{1}{c}{ Élelmiszerek (Foods) } & $\begin{array}{c}\text { Koffein tartalom (Caffeine } \\
\text { content) }\end{array}$ \\
\hline Egy csésze hosszú kávé (A cup of long coffee) & $90-180 \mathrm{mg} / 2 \mathrm{dl}$ \\
\hline Egy csésze presszó kávé (A cup of espresso coffee) & $75-110 \mathrm{mg} / \mathrm{o}, 5 \mathrm{dl}$ \\
\hline Egy csésze dupla kávé (A cup of double coffee) & $50-175 \mathrm{mg} / 1 \mathrm{dl}$ \\
\hline Energiaital (Energy drink) & $50-90 \mathrm{mg} / 2 \mathrm{dl}$ \\
\hline Egy csésze instant kávé (A cup of instant coffee) & $30-65 \mathrm{mg} / 1 \mathrm{dl}$ \\
\hline Egy csésze fekete tea (A cup of black tea) & $20-90 \mathrm{mg} / 2 \mathrm{dl}$ \\
\hline Egy csésze zöld tea (A cup of green tea) & $30-40 \mathrm{mg} / 2 \mathrm{dl}$ \\
\hline Egy pohár kóla (A glass of cola) & $20-35 \mathrm{mg} / 2 \mathrm{dl}$ \\
\hline Csokoládé (Chocolate) & $10-30 \mathrm{mg} / 3 \mathrm{dkg}$ \\
\hline Egy pohár kakaó (A glass of cocoa) & $10-20 \mathrm{mg} / 2 \mathrm{dl}$ \\
\hline Egy csésze koffeinmentes kávé (A cup of decaffeinated coffee) & $3-4 \mathrm{mg} / 2 \mathrm{dl}$ \\
\hline
\end{tabular}

Forrás (Source): MELION és TÚRY, 1992

\section{SzAKIRODALMI ÁTTEKINTÉS - LITERATURE REVIEW}

\subsection{A kávé jótékony egészségügyi hatásai - Beneficial Health Effects of Coffee}

A kávé legfő́bb hatóanyagai a purinvázas alkaloidok és polifenolok, utóbbi csoportból kiemelkedik a klorogénsav, amely a gyomorba kerülés során hidrolizálódik és kávésavvá alakul, majd pedig ez a vegyület konjugálódik (WILLIAMSON et al., 2009). A kolorogénsavnak számos hatása ismert, többek között képes gátolni a glükóz-6-foszfatáz enzim múködését, ami pedig lecsökkentheti a májban a glükóztermelést, azonban a koffein képes lehet a hasnyálmirigyben a $\beta$-sejteket inzulintermelésre ösztönözni (KHARE, 2007). Egy normál csésze kávéban átlagosan 80 mg koffein, a hazánkban népszerủ rövid kávéban pedig nagyjából $50 \mathrm{mg}$ koffein található; ami megközelítőleg megegyezik azzal a mennyiséggel, mint ami egy csésze teában található. A koffein egyik jellegzetes tulajdonsága, hogy a gyomorrendszerból hamar felszivódik, fehérjékhez kötődik és ezáltal képes a szervezet számtalan részébe eljutni. A kávé fogyasztása során a koffein szervezetbe kerülése által fokozódik gyomornedvtermelés, serkenti a szív- és a vesemúködését, vizelethajtó hatású, légzőközpontot izgató, vérnyomásemelést fejt ki átmenetileg, a migrént és az asztmás rohamot pedig bizonyos mértékben csillapítja (NEUWINGER, 2000; MILLS et al., 2006), mindazonáltal a kávé fogyasztása mérsékli a fáradtságot és fokozza a koncentrációképességet is (KHARE, 2007).

\section{KÉP}

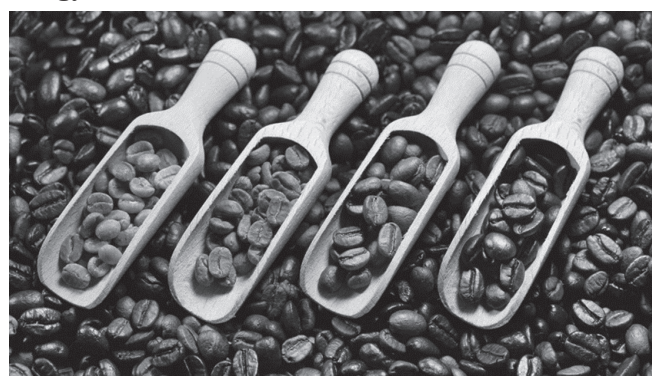

Pörkölt kávéváltozatok (Roasted Coffee Variants)

PICTURE 1

Forrás (Source): Getty Images, 2020 
$\mathrm{Az}$ égetés során nyert kávészenet, egyes esetekben használják akut, nem specifikus hasmenések megszüntetésére vagy mérséklésére, illetve szájüregi gyulladások kezelésére is (KHARE, 2007). A koffeinnek, diterpéneknek, kávésavnak, polifenoloknak, illóolajnak, valamint a heterociklilus molekuláknak köszönhetően a kávé rendszeres fogyasztása jelentősen csökkentheti a vese-, máj- és kisebb mértékben a premenopauzális mell- és vastagbélrák kialakulását (NKONDJOCK, 2009).

Tesztek igazolták, hogy a zöld mag kivonatai lokális alkalmazás során gyulladáscsökkentő hatással rendelkeznek. Egereken végzett kísérletek során bebizonyosodott, hogy a termésből készített kivonatok daganatellenes és vércukorszint-csökkentő hatásúak (ROSS, 2005).

A koffein egyik kevésbé ismert hatása az, hogy az idős fogyasztók esetében aluszékonyságot válthat ki. Ennek az a magyarázata, hogy mivel a kávé fogyasztása növeli a szív teljesítményét, ezáltal pedig javítja az agy vérellátását, ennek következtében könnyíti az elalvást. Egy másik kevesek által ismert hatás, hogy kis adagban segítheti a dohányzásról való leszokást is (STÁJER, 2004). Mindezek mellett megemlítendő még az édességipar és a cukrászdák kávéfelhasználása is, mind lefözve, mind egész szemenként vagy szén formában hasznosítva (KHARE, 2007).

A kávéból készült kivonat nemcsak szájon át, hanem lokálisan, azaz helyileg is alkalmazható, mivel a kivonat gazdagnak tekinthető antioxidáns hatású vegyületekben, emellett pedig fényvédelemben és a daganatos megbetegedések megelőzésében is szerepet játszhat. Egy klinikai vizsgálatban 30 bőrkárosodásban szenvedő beteget kávémagkivonatot tartalmazó bőrvédő szerrel teszteltek. A vizsgált termékkel 20 beteg teljes arcfelületét, 10 beteg esetében csak a fél arcfelületet, a maradék felületet pedig placebó hatású krémmel kezelték. A placebó hatású krémhez képest a vizsgált termék szemmel láthatóan javított a finom vonalakon, csökkentette a ráncokat, a pigmentációt, továbbá ezek mellett javította a betegek arcbörének megjelenését (COOPER és KRONENBERG 2009).

\subsection{A kávé káros egészségügyi hatásai - Adverse Health Effects of Coffee}

Kávé fogyasztása esetén figyelembe kell vennünk az ezzel párhuzamosan történő gyógyszeres kezelést is, az esetlegesen kialakuló interakciók lehetősége miatt. A kávé számtalan gyógynövény hatását semlegesítheti, az aszpirin és paracetamol hatását pedig akár fokozhatja is. Nagy mennyiségü kávéfogyasztás során a szervezetben lecsökkenhet a B-vitamin koncentráció, ami néhány esetben akár súlyos következményekkel is járhat (KHARE, 2007).

A kávéfogyasztásnak számos, az emberi szervezetre kedvezőtlen mellékhatását tartjuk számon, melyek például a bélnyálkahártya ingerlékenysége, hasmenés, idegesség és gyomorfekély (BABULKA et al., 2012). Abban az esetben, ha a szervezetben a koffein koncentrációja meghaladja a napi $1,5 \mathrm{~g}$ mennyiséget, akár súlyos mellékhatások is felléphetnek, például a magas vérnyomás, zsibbadás, izomgörcsök, hallucinációk, a hát izmainak hosszú ideig tartó görcse és szélsőséges esetekben akár légzésbénulás. A felnőttek számára halálos dózis 150-200 mg koffein/kg jelenlétét jelenti a szervezetben. Nem ajánlott a kávé kis mértékű fogyasztása sem azok számára, akik magas vérnyomásban, szívkoszorúér-betegségben, vese- és egyes idegrendszeri betegségekben és gyomorfekélyben szenvednek, vagy nyugtalan és koffeinérzékeny egyének, illetve kismamák és gyermekek számára (ISTUDOR, 2005).

A kávé nagy mennyiségű fogyasztása a koffein hatása által koffeinizmushoz vezethet. Naponta több mint 5 kávé fogyasztása a kávé túladagolását jelenti, melynek következményei az ingerlékenység, remegés, alvászavar, hányás, hasmenés, fejfájás, és nagyon ritkán halál is lehet. Túladagolás esetén azonban fóként a gyermekek esetében fordult elő halál. Ezekben az esetekben az első tünet a hányás és később hasizomgörcsök is jelentkeznek. Túladagolás esetén fontos az elsősegélynyújtás, ami a hányás mesterséges előidézéséből, gyomormosásból, diazepám és görcsoldók alkalmazásából áll (STÁJER, 2004). A kávé rendszeres fogyasztása a gyomorsavszint növekedését is eredményezheti, emellett a napi 7 csésze kávé alkohol-, valamint cigarettafogyasztással együtt az öngyilkosságra való hajlamot is növelheti (ROSS, 2005). 
Az alábbi 2. táblázatba rendszereztük és összesítettük a kávé korábban már említett je- lentősebb jótékony és káros egészségügyi hatásait, a teljesség igényei nélkül.

2. TÁBLÁZAT

TABLE 2 A kávé fontosabb jótékony és káros egészségügyi hatásai (The Important Beneficial and Harmful Health Effects of Coffee)

\begin{tabular}{lc}
\hline \multicolumn{1}{c}{$\begin{array}{c}\text { A kávé jótékony egészségügyi hatásai (Beneficial } \\
\text { health effects of coffee) }\end{array}$} & $\begin{array}{c}\text { A kávé káros egészségügyi hatásai (Adverse } \\
\text { health effects of coffee) }\end{array}$ \\
\hline $\begin{array}{l}\text { szív- és vesemúködés serkentés (stimulation of heart and } \\
\text { kidney function) }\end{array}$ & vérnyomás növelés (increase in blood pressure) \\
\hline hasmenés megszüntetése (elimination of diarrhea) & függöséget okozhat (it can cause addiction) \\
\hline $\begin{array}{l}\text { lokálisan ráncok csökkentése (locally use-wrinkle } \\
\text { reduction) }\end{array}$ & várandósokra veszélyes (it can be dangerous for \\
\hline Forrás (Source): STÁJER 2004; ROSS 2005; KHARE 2007; COOPER és KRONENBERG
\end{tabular}

Célkitűzésünk a kávéfogyasztási szokások egészségre gyakorolt hatásainak feltárása, illetve az azzal kapcsolatos tudatosság vizsgálata hazai szinten, szekunder adatgyújtésre alapozott kérdőíves felmérés eredményei által. Kutatásaink kapcsán a következő hipotézist határoztuk meg, azon kitöltőkre vonatkoztatva, akik gyakran, azaz legalább napi egy kávét fogyasztanak: „Azok a kitöltők, akik gyakran fogyasztanak kávét, nincsenek tisztában a kávé egészségügyi hatásaival”. Hipotézisünket a kapott eredményeink függvényében igazoltuk vagy elvetettük.

\section{ANYAG ÉS MÓDSZER - MATERIAL AND METHOD}

A kutatásunkhoz egyaránt használtunk szekunder és primer információgyüjtést. Először a szekunder adatok gyưjtését, rendszerezését kezdtük meg, majd pedig ezek adaptálását, elemzését végeztük el. Szekunder kutatásunk tekintetében a témához kapcsolódó adatbázisokat, kutatási anyagokat használtuk fel, primer részról pedig a társadalom kávéfogyasztási szokásait vizsgáltuk. A primer információgyüjtésünk során kérdőives fogyasztói megkérdezést alkalmaztunk Magyarország lakosai körében, a kutatás azonban nem volt reprezentatív. A kérdőívet először néhány fő bevonásával teszteltük, az észlelt hibákat javítottuk, majd megkezdtük a kérdőív széleskörü terjesztését.

Szekunder adatgyüjtésünk során elsőként szakirodalmak áttekintését végeztük, mely által sikerült a témára részletes rálátást szerez- nünk. Hazai és nemzetközi szakirodalom-kutatást és -rendszerezést egyaránt végeztünk. Ezek alapját a témához szorosan kötődő különböző könyvek, tudományos folyóiratcikkek és internetes források egyaránt képzik. A kávétermeléssel és fogyasztással kapcsolatos adatokat a Nemzetközi Kávé Szervezet (International Coffee Organization, ICO) és a Központi Statisztikai Hivatal (KSH) adatbázisából gyüjtöttük össze. A felhasznált adatok esetében igyekeztünk mindig a legfrissebb elérhető adatokra támaszkodni, mely segítséget nyújt az ágazat aktuális helyzetének megismerésére.

A szekunder információgyüjtésünket kiegészítettük a primer adatgyưjitéssel, melyhez fogyasztói megkérdezést alkalmaztunk. Kutatásunk ezen részét online kérdőív segítségével végeztük, melyet a www.docs.google.com felületen készítettünk el. Válaszadóinkat interneten, közösségi oldalakon céloztuk meg, fiatalokat, azaz 18 év alattiakat, időseket, azaz 60 év fölöttieket és a közbeeső korosztályt egyaránt. A 18 év alatti kitöltők esetében a válaszadáshoz szükséges szülői beleegyezés megtörtént. Ismerőseink, azok ismerősei és számtalan számunkra idegen ember töltötte ki a kérdőívet, akiket többnyire kávékedvelő csoportokban értünk el. Kérdőívünkre 1664 értékelhető kitöltés érkezett. Az adatgyưjités közel egy hónapig tartott, 2020. március elejétől, március végéig.

A rendelkezésre álló adataink elemzéséhez leíró statisztikai módszereket, majd ezt követően nem-paraméteres eljárásokat alkalmaztunk az Excel táblázatkezelő program és az SPSS statisztikai szoftver segítségével. A leíró statisztikai módszerek tekintetében az egyes kérdésekre adott összes válasz bemutatásra kerül, ami 
által azt tudjuk megállapítani, hogy egy-egy válaszlehetőséget hány kitöltő jelölt meg, illetve, hogy az egyes kategóriát a válaszadók hány százaléka jelölte meg (DOGI et al., 2014). Ezen módszerek közül a leggyakrabban használt eljárás a számtani átlag és a szórás, melyeket kutatásunk során alkalmaztunk.

Kérdéseinkkel arra kerestük a választ, hogy a válaszadók fogyasztanak-e kávét, ha igen, milyen gyakorisággal, illetve mennyire vannak tisztában a kávé egészségügyi hatásaival. A háttérváltozók közül a nemre, életkorra, lakóhely-

3/A. TÁBLÁZAT

A mintasokaság szocio-demográfiai megoszlása (Socio-demographic Distribution of the Sample Population) $(\mathrm{N}=1664)$

\begin{tabular}{|c|c|c|}
\hline \multirow[t]{2}{*}{$\begin{array}{l}\text { Szocio-demográfiai változók } \\
\text { (Socio-demographic variables) }\end{array}$} & \multicolumn{2}{|c|}{$\begin{array}{c}\text { A minta megoszlása } \\
\text { (Distribution of the } \\
\text { sample) }\end{array}$} \\
\hline & $\mathbf{N}$ & $\%$ \\
\hline Összes kitöltő (All respondents) & 1664 & 100,0 \\
\hline \multicolumn{3}{|l|}{$\operatorname{Nem}(\operatorname{Sex})$} \\
\hline Nő (Woman) & 1279 & 76,9 \\
\hline Férfi (Man) & 385 & 23,1 \\
\hline \multicolumn{3}{|l|}{ Kor (Age) } \\
\hline 18 év alatti (under 18 years) & 73 & 4,4 \\
\hline $18-30$ & 1207 & 72,4 \\
\hline $31-40$ & 199 & 12,1 \\
\hline $41-50$ & 123 & 7,4 \\
\hline $51-60$ & 47 & 2,8 \\
\hline 60 év fölötti (above 60 years) & 15 & 0,9 \\
\hline \multicolumn{3}{|l|}{ Iskolai végzettség (Level of education) } \\
\hline 8 általános vagy annál kevesebb (elementary school or less) & 90 & 5,4 \\
\hline szakmunkás (vocational training) & 64 & 3,8 \\
\hline érettségi (baccalaureate) & 744 & 44,7 \\
\hline technikum (technical school) & 70 & 4,2 \\
\hline felsőfokú szakképesítés (tertiary qualifications) & 76 & 4,6 \\
\hline OKJ képzés (qualification listed in the National Qualifications Register) & 73 & 4,4 \\
\hline főiskolai végzettség (college degree) & 172 & 10,3 \\
\hline egyetemi végzettség (university degree) & 375 & 22,6 \\
\hline
\end{tabular}



Population) $(\mathrm{N}=1664)$

\begin{tabular}{|c|c|c|}
\hline \multirow[t]{2}{*}{$\begin{array}{c}\text { Szocio-demográfiai változók } \\
\text { (Socio-demographic variables) }\end{array}$} & \multicolumn{2}{|c|}{$\begin{array}{c}\text { A minta megoszlása } \\
\text { (Distribution of the } \\
\text { sample) }\end{array}$} \\
\hline & $\mathbf{N}$ & $\%$ \\
\hline \multicolumn{3}{|l|}{ Településtípus (Type of settlement) } \\
\hline tanya (farm) & 5 & 0,3 \\
\hline falu (village) & 237 & 14,2 \\
\hline község (town) & 216 & 13,0 \\
\hline város (city) & 537 & 32,3 \\
\hline megyeszékhely (county seat) & 460 & 27,6 \\
\hline fóváros (capital) & 209 & 12,6 \\
\hline \multicolumn{3}{|l|}{ Havi nettó jövedelem (Monthly net income) } \\
\hline 100 ooo Ft-nál kevesebb (less than 100 ooo Ft) & 293 & 17,6 \\
\hline 100 ooo-150 00o Ft & 277 & 16,6 \\
\hline $150001-199999 \mathrm{Ft}$ & 112 & 6,7 \\
\hline $200000-300000 \mathrm{Ft}$ & 304 & 18,3 \\
\hline 300 ooo Ft-nál több (more than 300 ooo Ft) & 143 & 8,6 \\
\hline nem rendelkezik jövedelemmel (has no income) & 535 & 32,2 \\
\hline
\end{tabular}

Forrás (Source): Saját adatgyújtés, 2020 (Authors'own data collection, 2020)

A szocio-demográfiai adatok alapján öszszességében elmondható, hogy válaszadóink széleskörűen többféle korosztályból kerültek ki. A kitöltők életkora 18 év alattitól egészen a 60 év fölötti korosztályig váltakozik. Legnagyobb arányban, 72,6\%-ban 18-30 év közötti korosztályt sikerült elérnünk az internetes közösségi oldalak által. Iskolai végzettséget tekintve az érettségivel és az egyetemi végzettséggel rendelkezők voltak nagyobb arányban, mely a korosztályokat tekintve elfogadható. Településtípus alapján a fơvárosban, városban és megyeszékhelyen élők száma együttvéve az összes kitöltő több mint felét teszi ki. A nettó havi jövedelem szempontjából a kitöltők 32,2\%-a nem rendelkezik jövedelemmel, ami visszacsatolható ahhoz, hogy korosztályt tekintve a fiatalok nagyobb többségben töltötték ki a kérdőívet, illetve a kitöltéskor csak érettségi bizonyítvánnyal rendelkeztek, így valószínúsíthető, hogy jelenleg folyamatban vannak a felsőfokú tanulmányaik.

Nemek szerinti megoszlást tekintve, a nők 74,4\%-a gyakran, azaz naponta legalább egyszer, $17,4 \%$-a alkalmanként, azaz hetente né- hány vagy ennél kevesebb alkalommal és 8,1\%a soha nem fogyaszt kávét. Férfiak esetében $64,7 \%$ gyakran, 20,8\% alkalmanként és $14,5 \%$ egyáltalán nem fogyasztja az említett italt. Ebból megállapítható, hogy a nők esetében több a gyakrabban kávét fogyasztó, míg a férfiak esetében közel kétszerese a nókkel szemben a soha nem fogyasztók aránya.

A kitöltők több mint fele (56\%) 2-3 csésze kávét fogyaszt naponta, míg a kitöltók 33\%-a csupán 1 csészényit. Vannak azonban (10\%), akik 4-5 csészével fogyasztanak, és bár kevesen (1\%), de vannak, akik 6 vagy annál több csésze kávét isznak meg egy nap alatt. Azok a kitöltők, akik gyakran kávéznak ( $\mathrm{N}=1201)$, 65,6\%-ban naponta 2-3 csésze kávét fogyasztanak, 20,7\%ban csupán 1 csészényit, 12\%-ban 4-5 csészével, 1,7\%-ban pedig 6 vagy több csésze kávét fogyasztanak el egy nap alatt.

Következő kérdésünkben azt próbáltuk feltárni, hogy kitöltőink általában hol fogyasztanak kávét. Erre a kérdésre négy válaszlehetőség közül lehetett választani, melyek a következők voltak: otthon, családtagnál vagy barátnál, kávézóban, munkahelyen. Ebben a kérdésben 
lehetőség volt több választ is megjelölni, mivel úgy gondoltuk, hogy akik naponta többször fogyasztanak kávét, nem biztos, hogy csak egy helyen teszik azt. A válaszadók túlnyomó többsége, azaz 1327 kitöltő az otthonában preferálja elfogyasztani a kávéját. Ezt követik azok, akik munkahelyükön teszik ezt inkább, azaz 698 fó. Az egyes kombinációk tanulmányozása során, arra a megállapításra jutottunk, hogy a leggyakoribb válaszok az otthon és a munkahelyek voltak. Ennek nagy valószínúséggel az lehet az oka, hogy sokan kávéval indítják napjukat otthon, majd pedig napközben a munkahelyükön is elfogyasztanak egy csészével. Ez visszacsatolható az előző kérdéshez, melyből kiderült, hogy a válaszadók többsége 2-3 csésze kávét fogyaszt naponta.

A kávé intenzitását vizsgálva megállapítottuk, hogy azok a kitöltők, akik általában napi 1 csésze kávét fogyasztanak, a nók esetében 51\%ban 5-7-es erősségü, kiegyensúlyozott, ízekben gazdag, míg 38\%-ban 1-4-es erősségű nem túl testes, lágy kávét választanak. 8-10-es intenzitású testes és kifejezetten aromás kávét a nők csupán 9\%-a fogyasztja. Koffeinmentes kávé esetében ez az arány 2\%-nak felel meg. Férfiak esetében, szintén az 1 csészével fogyasztókat tekintve, 54\%-ban 5-7-es erősségü, kiegyensúlyozott, ízekben gazdag, és 27\%-ban 1-4-es erősségü nem túl testes, lágy ízủ kávét fogyasztanak. A 8-10-es intenzitású testes és kifejezetten aromás kávét a naponta egy csészével fogyasztó férfiak 17\%-a, míg koffeinmentes kávét 2\%-a fogyaszt. Mindezekkel szemben, azok a válaszadók, akik naponta 4-5 csésze kávét fogyasztanak, nőket tekintve 45,7\%-ban 5-7-es erősségü, kiegyensúlyozott, ízekben gazdag, míg 27,7\%-ban 8-10-es intenzitású testes és kifejezetten aromás kávét fogyasztanak. Ezen kitöltők 24,5\%-ban 1-4-es erősségű nem túl testes, lágy kávét választanak, koffeinmentest pedig 2,1\%-uk fogyaszt. Azok a férfiak, akik naponta 4-5 csésze kávét isznak, 49\%-ban 8-10es intenzitású testes és kifejezetten aromásat, 43,2\%-ban 5-7-es erősségú, kiegyensúlyozott, ízekben gazdagot és 7,8\%-ban 1-4-es erősségü nem túl testes, lágy kávét részesítenek előnyben. A kapott eredményeink alapján elmondható, hogy azon csoportba tartozó férfi válaszadók, akik naponta 4-5 csésze kávét isznak nem fogyasztanak koffeinmentes kávét. Ezek alapján kijelenthető, hogy az 5-7-es erősségü, kiegyensúlyozott, ízekben gazdag kávéváltozat a legnépszerúbb a napi 1 és a napi 4-5 csésze kávét fogyasztók csoportjában egyaránt. Mindazonáltal a napi 1 csészével fogyasztók második legkedveltebb változata az 1-4-es erősségü nem túl testes, lágy kávé, ezzel szemben a napi 4-5 csészével fogyasztók számára a második helyen a 8-10-es intenzitású testes és kifejezetten aromás kávé szerepel.

Megvizsgáltuk továbbá, a kitöltők kávéfogyasztásának okát. Megállapítottuk, hogy azoknak a kitöltőknek a 10\%-a, akik fogyasztanak kávét, valamilyen egészségügyi okból teszi azt. Ezek az egészségügyi okok a vérnyomásnövelés, az értágítás vagy számos más, az egészségre jótékony hatás.

Számos más ital is tartalmaz koffeint, így ezek a kávé versenytársainak is tekinthetők. A kávé versenytársai közé tartozik a tea, kóla és az energiaital. Ezek közül kiemelkedik az energiaital mely esetében a legnagyobb a fogyasztók általi megosztottság aránya, azonban mégis a kávé legnagyobb versenytárs termékének tekinthető (BERENCSI és FEHÉR, 2020). Kérdőívünkben kitértünk arra, hogy kitöltőink milyen serkentő hatású italokat fogyasztanak. Erre a kérdésre több válaszlehetőséget is megadhattak, hiszen van olyan, aki mind a négy terméket fogyasztja néha. A vizsgált mintasokaság legnagyobb része kávét fogyaszt, majd ezt követte a tea. 424 fó, azaz a teljes mintasokaság 25\%-a, csak és kizárólag kávét és teát fogyaszt. Azok a kitöltők, akik nem fogyasztanak kávét, legnagyobb arányban, 47\%, teát isznak, majd ezt követi a kóla 35\%-kal és az energiaital 18\%-kal. A tea fogyasztása fóként az idősebb, 30 év fölötti kitöltőkre jellemző, míg a kóla és az energiaital leginkább a fiatal, 30 év alatti kitöltők kedvelt itala.

A következőkben a kávé egészségügyi hatásaival kapcsolatos tudatosságot vizsgáltuk. Megállapítottuk, hogy a kávét gyakran fogyasztó kitöltők közül a nők, a szintén gyakran fogyasztó férfiakkal szemben, tudatosabbak a kávé egészségre gyakorolt hatásaival kapcsolatban. Ezt az alábbi (1. ábra) diagramon szemléltettük, a két nemet külön megjelenítve. A nők 69\%-a a kávé jótékony és káros tulajdonságaival egyaránt tisztában van, míg a férfiaknak csak 21\%-a van tisztában a kávé jótékony és ká- 
ros egészségügyi hatásával. A nők 19\%-a csak a kávé jótékony egészségügyi hatásaival van tisztában, míg a férfiak esetében ez az arány csupán $6 \%$ volt. Jelentősen nagyobb eltérés figyelhető meg, a kávéfogyasztás káros hatásait vizsgálva, hiszen ebben az esetben a nők csak 5\%-a van ezzel tisztában, a férfiaknak viszont a legnagyobb része, 66\%-a ismeri a kávé káros egészségügyi hatásait. Mindkét nem esetében 7\% azok aránya, akik egyáltalán nincsenek tisztában a kávé egészségügyi hatásaival.
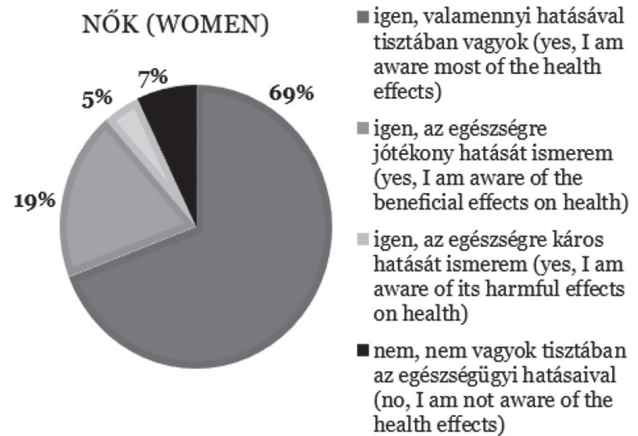
tisztában vagyok (yes, I am aware most of the health effects)

-igen, az egészségre jótékony hatását ismerem (yes, I am aware of the beneficial effects on health)

" igen, az egészségre káros hatását ismerem (yes, I am aware of its harmful effects on health)

mem, nem vagyok tisztában az egészségügyi hatásaival (no, I am not aware of the health effects)

FIG. 1

1. ÁBRA

Egészségre gyakorolt hatásokkal kapcsolatos tudatosság, kávét gyakran fogyasztó nők $(\mathrm{N}=952)$ és férfiak $(\mathrm{N}=249)$ esetében

(Awareness of Health Effects for Women $(N=952)$ and men $(N=249)$ who Frequently Drink Coffee)

Forrás (Source): Saját szerkesztés (Authors'own compilation)

Azok a válaszadók, akik tisztában vannak a kávé valamennyi jótékony és káros egészségügyi hatásával, napi mennyiséget tekintve 49,4\%-ban 2-3 csészével, 28,6\%-ban 1 csészével, 20,4\%-ban 4-5 csészével és 1,6\%-ban 6 vagy több csészével fogyasztanak. A fogyasztott kávé erősségét tekintve, szintén azok, akik tisztában vannak a kávé valamennyi jótékony és káros egészségügyi hatásával, 53,5\%-ban 5-7es erősségű, kiegyensúlyozott, ízekben gazdag, 23,4\%-ban 1-4-es erősségü nem túl testes, lágy kávét, 22,2\%-ban 8-10-es intenzitású testes és kifejezetten aromás, 0,9\%-ban pedig koffeinmentes kávéváltozatot fogyasztanak. Ezen eredmények alapján az jelenthető ki, hogy akik tisztában vannak a kávé valamennyi jótékony és káros egészségre kiható tulajdonságával, nem tudatosabbak azokkal szemben, akik csak a jó, a rossz, vagy egyik tulajdonságával sincsenek tisztában.

\section{KöVETKEZTETÉSEK ÉS} JAVASLATOK - CONCLUSIONS AND Proposals

Kutatásunk célja a kávéfogyasztási szokások felmérése volt a hazai lakosok körében. A szakirodalmak tanulmányozása és az általunk készített kérdőív kiértékelése nagyban hozzájárult ahhoz, hogy részletes rálátással legyünk a témára, melyek által egy átfogó képet tudtunk nyújtani kutatásaink eredményeképpen.

Fontos kijelenteni, hogy bár a minta viszonylag nagy és széleskörü, a mintasokaság statisztikailag nem reprezentálja Magyarország lakosságát, ezért a felmérést nem tekintjük reprezentatívnak, az eredmények csupán feltáró jellegüek.

A kérdőívünk kitöltőinek válaszai alapján kijelenthető, hogy a válaszadók nagy része gyakran fogyaszt kávét, napi 2-3 csészével, 
melyet legnagyobb arányban, otthonukban és munkahelyükön tesznek meg. Nemek szerinti megoszlást tekintve a nők esetében magasabb a gyakran kávézók aránya. Továbbá megállapítottuk, hogy a kitöltők 10\%-a egészségügyi okokból fogyaszt kávét, mely okok lehetnek a vérnyomásnövelés vagy akár értágítás. Kiderült, hogy a gyakran kávézó nók esetében magasabb azok aránya, akik a kávé valamennyi jótékony és káros egészségügyi hatását ismerik, míg a szintén gyakran kávézó férfiakra inkább az a jellemző, hogy csak a kávé egészségre káros hatásait ismerik.

A kérdőív kiértékelése után megállapítottuk, hogy a hipotézisünk, mely szerint „Azok a kitöltők, akik gyakran fogyasztanak kávét, nincsenek tisztában a kávé egészségügyi hatásaival.” nem igazolható teljes mértékben. A kapott eredmények alapján megállapítható, hogy bár összességében a kitöltők 69\%-a a saját állítása szerint a kávé valamennyi jótékony és káros egészségügyi hatásával tisztában van, a nőkre igen (69\%), míg a férfiakra kevésbé igazolódik be az állítás (21\%). A kitöltő férfiak nagy része (66\%) csak a kávé egészségre káros hatásaival van tisztában, mely arány a nók esetében jóval alacsonyabb mértékü (5\%). Kutatásaink során a kapott válaszok alapján megállapítottuk, hogy a fogyasztott kávé mennyiségét és erősségét tekintve, akik tisztában vannak a kávé valamennyi jótékony és káros egészségre kiható tulajdonságával, nem tudatosabbak azokkal szemben, akik csak a jó, rossz vagy egyik tulajdonságával sincsenek tisztában.

Annak ellenére, hogy a vizsgált mintasokaság nem volt reprezentatív, és az eredményeket nem lehet általánosítani, az általunk végzett kutatás mégis áttekintést adhat olyan fö tényezőkről, amelyek befolyásolhatják a fogyasztók döntéseit kávé vásárlása és fogyasztása során. Véleményünk szerint fontos lenne, hogy a kávét fogyasztók tisztában legyenek az általuk vásárolt kávé jótékony és káros egészségügyi hatásaival egyaránt, hiszen vannak, akik napi több csészével fogyasztják, és nem tudják, hogy milyen következményei lehetnek ennek a későbbiekben.

Bár a döntés a vásárlók kezében van, hogy milyen fajta kávét milyen gyakorisággal fogyasztanak, érdemes lenne, ha a jövőben az egészségügy különböző csatornákon tájékoz- tatná az embereket és felhívná a figyelmet a kávé egészségügyi hatásaira. Számtalan módon történhet ez a tájékoztatás, egy egyszerű megoldás lehet például plakátok, szórólapok elhelyezése az orvosi rendelőkben és az egészségügyi intézményekben. Az idősebb generáció elérése főként folyóiratok és rádió által, vagy a televízión keresztül célszerü, míg a fiatalabb korosztályt praktikus az interneten és a közösségi oldalakon megcélozni. Ezen tevékenységek mögé egészségügyi szervezetek, vagy nonprofit akciócsoportok állhatnának.

\section{6. ÖSSZEFOGLALÁS - SUMMARY}

A kávé egy népszerü, változatosan elkészíthető, széles körben elterjedt ital. A világ számos pontján ismerik és fogyasztják. A téma aktualitását erősíti az is, hogy világszintü és hazai adatokat tekintve a kávé fogyasztása évről évre növekvő tendenciát mutat. Fő alkotó vegyülete a koffein, mely jótékony és káros hatásairól egyaránt ismert. A koffein fóként élénkítő hatásáról népszerü, azonban fogyasztása során fontos a tudatosság és a mértékletesség.

Az általunk végzett kutatás legfóbb célkitûzése a kávéfogyasztási szokások feltárása volt hazai szinten, szekunder adatgyüjtésre alapozott kérdőíves felmérés eredményei által. További fontos célunk volt megvizsgálni a hazai fogyasztók tudatosságát a kávé egészségre gyakorolt jótékony és káros hatásaival kapcsolatban.

Szekunder kutatásunk után, mely számos a témában releváns szakirodalom felkutatását és rendszerezését jelentette, következett a primer kutatásunk, mely alapját az általunk készített kérdőív adta, melyben a válaszadóink kávéfogyasztással kapcsolatos magatartását vizsgáltuk. A kérdőívünket összesen 1664 fő töltötte ki, legnagyobb arányban női kitöltőink voltak és fóként a fiatal generációt sikerült elérnünk. Az általunk készített felmérés nem reprezentatív, a kapott eredményeink csupán feltáró jellegüek.

Kutatásunk során a válaszadók kávéfogyasztási preferenciáinak áttanulmányozása után megállapítottuk, hogy döntő többségük, azaz 72\%-uk fogyaszt napi rendszerességgel kávét, mely a nők esetében $74 \%$-os, a férfiak ese- 
tében pedig 65\%-os megoszlást jelent. Kapott eredményeink áttanulmányozása során arra a következtetésre jutottunk, hogy a vizsgált sokaság többsége napi 2-3 csésze kávét fogyaszt. A kávé intenzitását tekintve a legnépszerúbb az 5-7-es erősségü, kiegyensúlyozott, ízekben gazdag kávéváltozat lett, a napi 1 és a napi 4-5 csésze kávét fogyasztók csoportjában egyaránt.

A kávé egészségügyi hatásaival kapcsolatban számos jótékony és káros hatás ismert. A koffein a kávé mellett más élelmiszerekben is fellelhető, fogyasztása során fontos a tudatosság. A kitöltők többsége tisztában van a kávé jótékony és káros egészségügyi hatásaival egyaránt, a nók nagyobb arányban a férfiakkal szemben. További eredményeink alapján kiderült, hogy akik tisztában vannak a kávé valamennyi jótékony és káros egészségre kiható tulajdonságával, a fogyasztott kávé mennyiségét és erősségét tekintve nem tudatosabbak azokkal szemben, akik csak a jó, rossz vagy egyik tulajdonságával sincsenek tisztában.

\section{IRODALOMJEGYZÉK - REFERENCES}

Babulka, P. - Szabó, L. Gy. - Fődi, A.: Erény és bizalom. Képes szelektív gyógynövény- és gombaismertető DXN. Europe Kft., Budapest. 2012. 97-100.

Benmetan, T.: Kávéöv, fő kávétermelő országok. $2018 . \quad$ https://seasia. co/2018/01/27/the-coffee-belt-a-worldmap-of-the-major-coffee-producers (Letöltés dátuma: 2020.03.31.)

Berencsi, A. - Fehér, A.: Az energiaitalok fogyasztói és szakértői megítélésének kvalitatív elemzése. Táplálkozásmarketing. 2020. 7 (2) 51-63. DOI: https://doi. org/10.20494/TM/7/2/4

Chrysant, S. G.: The Impact of Coffee Consumption on Blood Pressure, Cardiovascular Disease and Diabetes Mellitus. Taylor \& Francis Online. 2017. 151-156.

Cooper, R. - Kronenberg, F.: Botanical Medicine. Mary Ann Liebert, New Rochelle. 2009. 51. DOI: https://doi. org/10.1021/acs.jnatprod.8booo10
Crozier, A. - Ashihara, H. - Tomás, B. F.: Teas, Cocoa and Coffee. Plant Secondary Metabolites and Health. Blackwell Publishing Ltd., Chichester, West Sussex. 2012. 4-5. DOI: https://doi.org/10.1007/ S10337-014-2673-1

Dogi, I. - Nagy, L. - Csipkés, M. - Balogh, P.: Kézmúves élelmiszerek vásárlásának fogyasztói magatartásvizsgálata a nők körében. Gazdálkodás. 2014. 58 (2) 160172.

Statista: Kávéfogyasztás fejenként. 2020. https://www.statista.com/ statistics / $292595 /$ global - coffeeconsumption/ (Letöltés dátuma: 2020.04.09.)

Getty Images: Pörkölt kávéváltozatok. 2020. https://www.gettyimages.com/detail/ photo/assorted-coffee-beans-royaltyfree-image/151993684?adppopup=true (Letöltés dátuma: 2020.04.07.)

Istudor, V.: Farmacognozie, Fitochimie, Fitoterapie. Vol. III. Editura Medicală, București. 2005. 265-266.

Khare, C. P.: Indian Medicinal Plants. Springer, Berlin. 2007. 164-165. DOI: https://doi.org/10.1007/978-0-38770638-2_354

Melion, J. - Túry, F.: A koffein pszichiátriai vonatkozásairól az irodalmi adatok tükrében. Végeken. 1992. 3 (3) 17-22.

Mills, E. - Duguoa, J. J. - Perri, D. - Koren, G.: Herbal Medicines in Pregnancy and Lactation. 2006.

Neuwinger, H. D.: African Traditional Medicine. Medpharm Scientific Publishers, Stuttgart. 2000. 130. DOI: https://doi.org/10.2307/1224546

Nkondjock, A.: Coffee Consumption and the Risk of Cancer. An overview. Cancer Letters. 2009. 121-125. DOI: https://doi. org/10.1016/j.canlet.2008.08.022

Rácz, J.: Növénynevek enciklopédiája. $\mathrm{Az}$ elnevezések eredete, a növények kultúrtörténete és élettani hatása. Tinta Könyvkiadó, Budapest. 2010. 393-395.

Ross, I. A.: Medicinal Plants of the World. Volume 3. Humana Press Inc., New Jersey. 2005. 155-184. 
OLÁH, B. - MiHÁLY-KARNAI, L.

Stájer, G.: Méregtől a gyógyszerig. Galenus Kiadó, Budapest. 2004. 121-133.
Williamson, E. - Driver, S. - Baxter, K.: Stockley's Herbal Medicines Interactions. Pharmaceutical Press, London. 2009. 145-187.

\section{JEGYZETEK $\nRightarrow$ NOTES}

